\title{
Identification of pyrazolotriazinones as potential agents for hyperuricemia treatment by using in vitro and in silico studies
}

\author{
M. Lourdes Sciú ${ }^{1} \cdot$ M. Daniela Santi ${ }^{2,3}$. Jorge Cantero ${ }^{4,5}$. Juan P. Colomer ${ }^{1} \cdot$ Margot Paulino-Zunini $^{4}$. \\ M. Gabriela Ortega ${ }^{2,3} \cdot$ E. Laura Moyano' ${ }^{10}$
}

Received: 7 February 2020 / Accepted: 15 April 2020 / Published online: 27 June 2020

(c) Springer Nature Switzerland AG 2020

\begin{abstract}
Heterocyclic compounds structurally related to purine bases have been described as anticonvulsants, antifungal, antiviral, anticancer, enzyme inhibitors, among others. In this work, pyrazolo[3,4-d][1-3]triazin-4-ones (2) and pyrazolo[4,3-d][1-3] triazin-4-ones (3) derivatives were evaluated as xanthine oxidase (XO) inhibitors. Compounds 3 showed the best activity with $\mathrm{IC}_{50}$ values range of $0.9-2.9 \mu \mathrm{M}$. While the inhibition performance of pyrazolotriazinones was not more active than reference inhibitor allopurinol $\left(I_{50}=0.247 \pm 0.004\right) \mu \mathrm{M}$, these nuclei provide a platform for new and more potent XO inhibitors. Accordingly, molecular modeling methods were carried out to understand the compounds-enzyme binding mode. First, we have performed a qualitative SAR study using the MOE ${ }^{\mathrm{TM}}$ SAR tool. This study showed three common scaffolds and the most active was identified. These results are certainly valuable and will be taken into account in future synthesis of structurally related compounds. Furthermore, QSAR 2D and 3D studies were performed and structural requirements for the activity are reported. The obtained results led us to present the structural improvements for the rational design and synthesis of new pyrazolotriazinone derivatives with greater xanthine oxidase inhibitory activity than allopurinol.
\end{abstract}

Keywords Docking · Pyrazolotriazine compounds · Anti-xanthine oxidase activity · 2D QSAR · 3D QSAR

\section{Introduction}

Hyperuricemia is a well-known disease produced by elevated levels of uric acid (UA) in the blood stream and it is considered as an important risk factor for the development of gout, nephrolithiasis, cardiovascular disease, hypertension and diabetes. Currently, the pharmacological treatment is to avoid the elevated levels of UA acting in the purine metabolism. One of the enzymes involved in this process is xanthine oxidase (XO). This enzyme is widely distributed, being found in bacteria, plants and humans [1]. $\mathrm{XO}$ has a total molecular weight of $300 \mathrm{kDa}$ and contains

M. Lourdes Sciu and M. Daniela Santi have contributed equally to this publication.

Electronic supplementary material The online version of this article (https://doi.org/10.1007/s42452-020-2756-6) contains supplementary material, which is available to authorized users.

$\bowtie$ M. Gabriela Ortega, gortega@fcq.unc.edu.ar; $\bowtie$ E. Laura Moyano, lauramoy@fcq.unc.edu|'Departamento de Química Orgánica-INFIQC, Facultad de Ciencias Químicas, Universidad Nacional de Córdoba, Haya de la torre y Medina Allende, Edificio Ciencias II, X5000HUA Córdoba, Argentina. ${ }^{2}$ Departamento de Ciencias Farmacéuticas-Farmacognosia, Facultad de Ciencias Químicas, Universidad Nacional de Córdoba, Haya de la Torre y Medina Allende, Edificio Ciencias II, X5000HUA Córdoba, Argentina. ${ }^{3}$ Instituto Multidisciplinario de Biología Vegetal (IMBIV-CONICET), Ciudad Universitaria, X5000HUA Córdoba, Argentina. ${ }^{4}$ Centro de Bioinformática Estructural (CeBiolnfo), Facultad de Química, Universidad de la República, Av. Gral. Flores 2124, 11800 Montevideo, Uruguay. ${ }^{5}$ Departamento de Investigación, Facultad de Ingeniería Agronómica, Universidad Nacional del Este, Km 17 1⁄2 Ruta Internacional № 7, Minga Guazú, Paraguay. 
a molybdenum cofactor (molybdopterin), two [2Fe-2S] clusters, and one FAD per subunit of the dimeric protein [1]. In the purine metabolism, XO oxidizes hypoxanthine to xanthine and this last one to uric acid (UA) [2-4]. Thus, human xanthine oxidase is considered a pharmacological target for the treatment of hyperuricemia. Allopurinol and febuxostat, well known inhibitors of $\mathrm{XO}$, have significant adverse effects such as allergic reactions, skin rashes, fever, hepatitis, nephropathy, among others [2,5]. Additionally, it has been reported that metabolites generated from the long-term administration of allopurinol could generate Stevens-Johnsons syndrome $[4,6]$.

Given the existing limitations in the treatment of hyperuricemia, there is an urgent need for discovery and development of new XO inhibitors with less or no side effects. In this context, several purine analogues were reported to display such kind of activity, such as 9-benzoyl-9-deazaguanines, 9-phenyl-8-azaguanines, 8-aryl-hipoxanthines and 8-azaadenine [7-10].

Due to their similarity with allopurinol, we evaluate two series of pyrazolotriazinone (PT) compounds with structural similarity to purine scaffold in terms of their in vitro inhibitory activity of XO. Additionally, the binding mode of these compounds with the enzyme was determined by molecular modeling. Although PTs did not attain the inhibitory capacity of allopurinol, the activity of some derivatives was within the same range of this reference compound. QSAR 2D and 3D studies were performed in order to explain the differences between the behaviour of PT derivatives and also to determinate the structural requirements to ensure a better inhibitory activity. The results here obtained provide valuable information regarding the structure-activity relationship of these purine-related compounds and led us to know the improvements necessary to synthesize, in the future, a new series of pyrazolotriazinone derivatives with better inhibitory activity of $\mathrm{XO}$, taking them as a valuable scaffold.

\section{Results and discussion}

\subsection{Synthesis of pyrazolotriazinone (PT) compounds}

Pyrazolo[3,4-d][1-3]triazin-4-ones (2) and pyrazolo[4,3d][1-3]triazin-4-ones (3) were synthesized from aminopyrazole-carbonitriles (1), as it is depicted in Scheme 1, following a diazotization protocol previously reported $[11,12]$.

\subsection{In vitro XO inhibition activity}

All synthesized PT compounds and allopurinol were tested in different concentrations in order to evaluate their inhibitory activity on XO.

Every compound was active in a concentration dependent manner and the $\mathrm{IC}_{50}$ values were estimated using nonlinear fitting of concentration-response data (Table 1). In comparison with allopurinol $\left[\mathrm{IC}_{50}=(0.247 \pm 0.004) \mu \mathrm{M}\right]$, the most active compounds were those corresponding to PTs $\mathbf{2}$, in the following descending order of activity: $\mathbf{2 e}>$ $\mathbf{2 a}>\mathbf{2} \mathbf{c}>\mathbf{2} \mathbf{f}>\mathbf{2} \mathbf{b}>\mathbf{2} \mathbf{g}>\mathbf{2 d}$. According to the experimental results, PT derivatives $\mathbf{3}$ displayed a slightly lower activity than 2, except for compound $\mathbf{3 c}$, which had a value of $\mathrm{IC}_{50}$ on the same order that $\mathbf{2 g}$ (Fig. 1).
Scheme 1 Synthesis of pyrazolo[3,4- $d][1-3]$ triazin-4-ones (PTs 2 ) and pyrazolo[4,3-d][1-3]triazin4-ones (PTs 3)

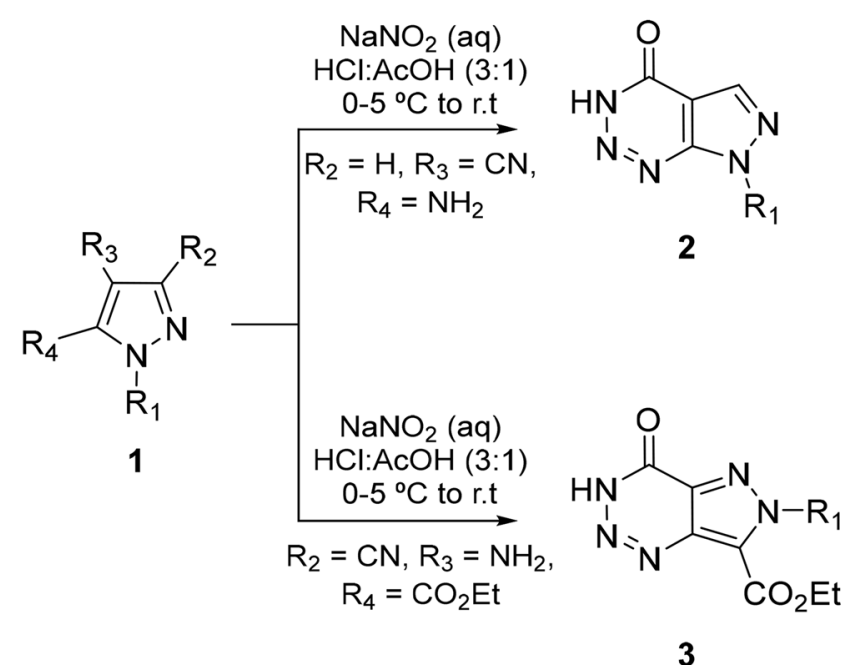

2a $\mathrm{R}_{1}=\mathrm{Ph}(77 \%)$

2b $\mathrm{R}_{1}=p-\mathrm{OCH}_{3}-\mathrm{C}_{6} \mathrm{H}_{4}(88 \%)$

2c $\mathrm{R}_{1}=p-\mathrm{F}-\mathrm{C}_{6} \mathrm{H}_{4}(70 \%)$

2d $\mathrm{R}_{1}=m-\mathrm{F}_{-} \mathrm{C}_{6} \mathrm{H}_{4}(52 \%)$

2e $\mathrm{R}_{1}=0-\mathrm{F}-\mathrm{C}_{6} \mathrm{H}_{4}(64 \%)$

$2 f \mathrm{R}_{1}=$ pyridin-2-yl (39\%)

$2 \mathrm{~g} \mathrm{R}_{1}=\operatorname{benzyl}(50 \%)$

3a $\mathrm{R}_{1}=\mathrm{Ph}(35 \%)$

3b R $\mathrm{R}_{1}=p-\mathrm{CH}_{3}-\mathrm{C}_{6} \mathrm{H}_{4}(38 \%)$

3c $\mathrm{R}_{1}=p-\mathrm{OCH}_{3}-\mathrm{C}_{6} \mathrm{H}_{4}(28 \%)$

3d $\mathrm{R}_{1}=p-\mathrm{Cl}-\mathrm{C}_{6} \mathrm{H}_{4}(31 \%)$

3e $\mathrm{R}_{1}=p-\mathrm{Br}-\mathrm{C}_{6} \mathrm{H}_{4}(36 \%)$

$3 f \mathrm{R}_{1}=p-\mid-\mathrm{C}_{6} \mathrm{H}_{4}(33 \%)$ 
Table 1 Xanthine oxidase inhibitory activity of pyrazolotriazinones derivatives

\begin{tabular}{|c|c|c|c|}
\hline Structure & Compound & $\mathrm{R}_{1}$ & $\mathrm{IC}_{50}(\mu \mathrm{M})^{\mathrm{b}}$ \\
\hline & Allopurinol $^{a}$ & $\mathrm{H}$ & $0.247 \pm 0.004$ \\
\hline & $2 a$ & $\mathrm{Ph}$ & $0.969 \pm 0.004$ \\
\hline & 2b & $p-\mathrm{OCH}_{3}-\mathrm{C}_{6} \mathrm{H}_{4}$ & $1.115 \pm 0.001$ \\
\hline & $2 c$ & $p-\mathrm{F}-\mathrm{C}_{6} \mathrm{H}_{4}$ & $0.97 \pm 0.01$ \\
\hline & 2d & $m-\mathrm{F}-\mathrm{C}_{6} \mathrm{H}_{4}$ & $2.929 \pm 0.001$ \\
\hline & $2 \mathbf{e}$ & $o-\mathrm{F}-\mathrm{C}_{6} \mathrm{H}_{4}$ & $0.907 \pm 0.004$ \\
\hline & $2 f$ & Pyridin-2-yl & $0.980 \pm 0.001$ \\
\hline & $2 g$ & Benzyl & $1.546 \pm 0.005$ \\
\hline & $3 a$ & $\mathrm{Ph}$ & $5.715 \pm 0.001$ \\
\hline & 3b & $p-\mathrm{CH}_{3}-\mathrm{C}_{6} \mathrm{H}_{4}$ & $3.96 \pm 0.02$ \\
\hline & $3 c$ & $p-\mathrm{OCH}_{3}-\mathrm{C}_{6} \mathrm{H}_{4}$ & $1.620 \pm 0.001$ \\
\hline & 3d & $p-\mathrm{Cl}-\mathrm{C}_{6} \mathrm{H}_{4}$ & $7.09 \pm 0.04$ \\
\hline & $3 e$ & $p-\mathrm{Br}-\mathrm{C}_{6} \mathrm{H}_{4}$ & $7.83 \pm 0.05$ \\
\hline & $3 f$ & $p-\mathrm{I}-\mathrm{C}_{6} \mathrm{H}_{4}$ & $8.56 \pm 0.02$ \\
\hline
\end{tabular}

apositive control

${ }^{\mathrm{b}}$ Average $\pm \mathrm{SD}$ of at least 3 determinations. $p<0.0001$, the values resulted significantly different to allopurinol

\subsection{Docking analysis}

Molecular modelling studies were carried out in order to understand the binding mode of the two PT families and XO (PDB ID: 3NVY) using MOE ${ }^{\mathrm{TM}} 2105.10$ software ("Molecular Operating Environment (MOE) 2015.10").

The PDB ID 3NVY is a crystal structure of bovine xanthine oxidase in complex with quercetin with a resolution

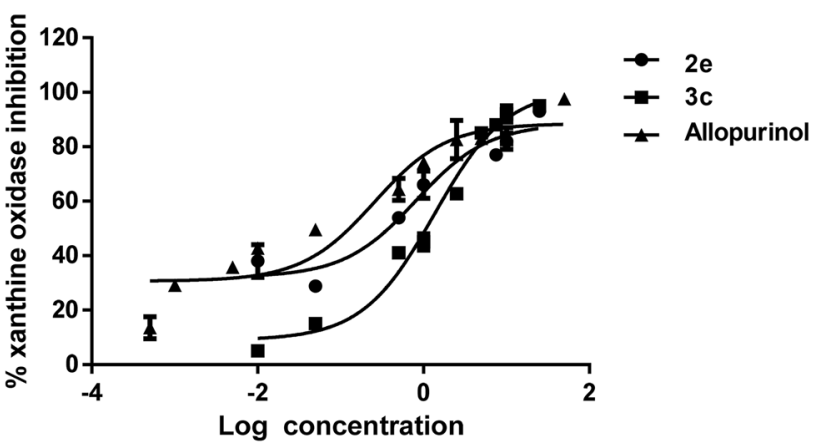

Fig. 1 Concentration-dependent xanthine oxidase inhibition for compounds $\mathbf{2 e}$ and $\mathbf{3 c}$, and the positive reference inhibitor allopurinol of $2.0 \AA$. It was considered the best selection because the localization of the active site is well defined and the involved residues are in the $9.0 \AA$ so here centered in quercetin. As site for docking was chosen a sphere of $9.0 \AA$ around the co-crystallized ligand, the flavonoid quercetin. The docking protocol was validated by re-docking quercetin trying to reproduce the same position observed in the co-crystallized ligand (described in the "Materials and methods" section) (Fig. 2).

The docking study yielded binding energy values for allopurinol and for the most actives of each series, $\mathbf{2} \mathbf{e}$ and $3 \mathrm{c}$ of $-10.42,-8.17$ and $-7.2 \mathrm{kcal} / \mathrm{mol}$ respectively, this being in accordance with that obtained on in vitro assays. The docking scores presented a good correlation with the bioactivity with an $r^{2}$ value of 0.76 .

Regarding the docking studies taking as "site" the residues annotated in a $9.0 \AA \AA$ sphere centered in quercetin, and after the cluster analysis, three different binding subsites were identified for the PT series. That result is shown in Fig. 3. Allopurinol, 2a, 2b, 2c, 2d, $\mathbf{2 e}$ and, $\mathbf{2} \mathbf{f}$ compounds were located into the same pocket site as quercetin, while $\mathbf{2 g}, \mathbf{3 a}, \mathbf{3 b}, \mathbf{3 c}$ and $\mathbf{3 d}$, showed a binding site located farther away, being those ligands more exposed to solvent. For the less active compounds, $\mathbf{3 e}$ and $\mathbf{3} \mathbf{f}$, the binding site was in the same pocket as quercetin, but more exposed. Those events could explain the potency differences in the inhibitory activity between both families of PT derivatives.

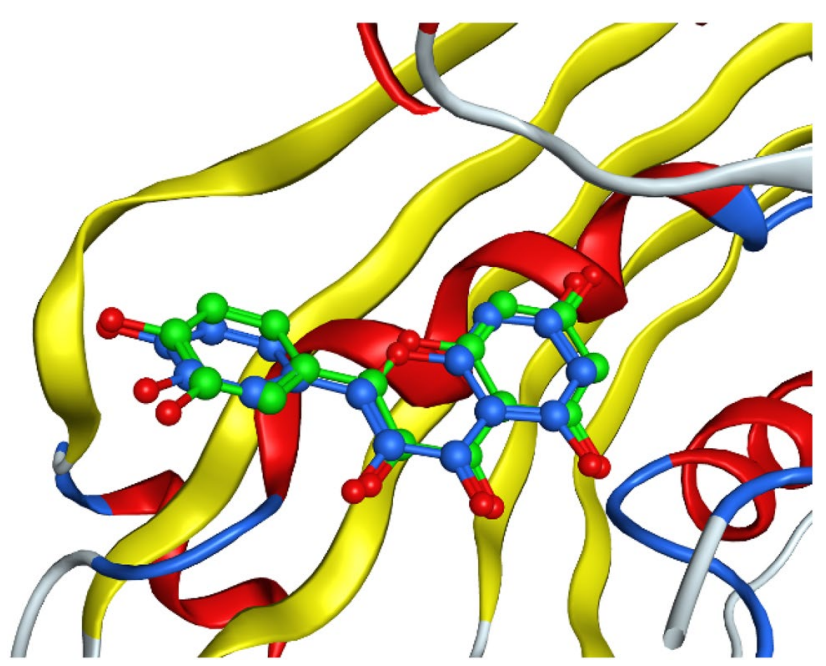

Fig. 2 Crystallographic structure of quercetin in complex with XO (PDB ID 3NVY) (green) and, quercetin resulting of docking pose validation (blue) 

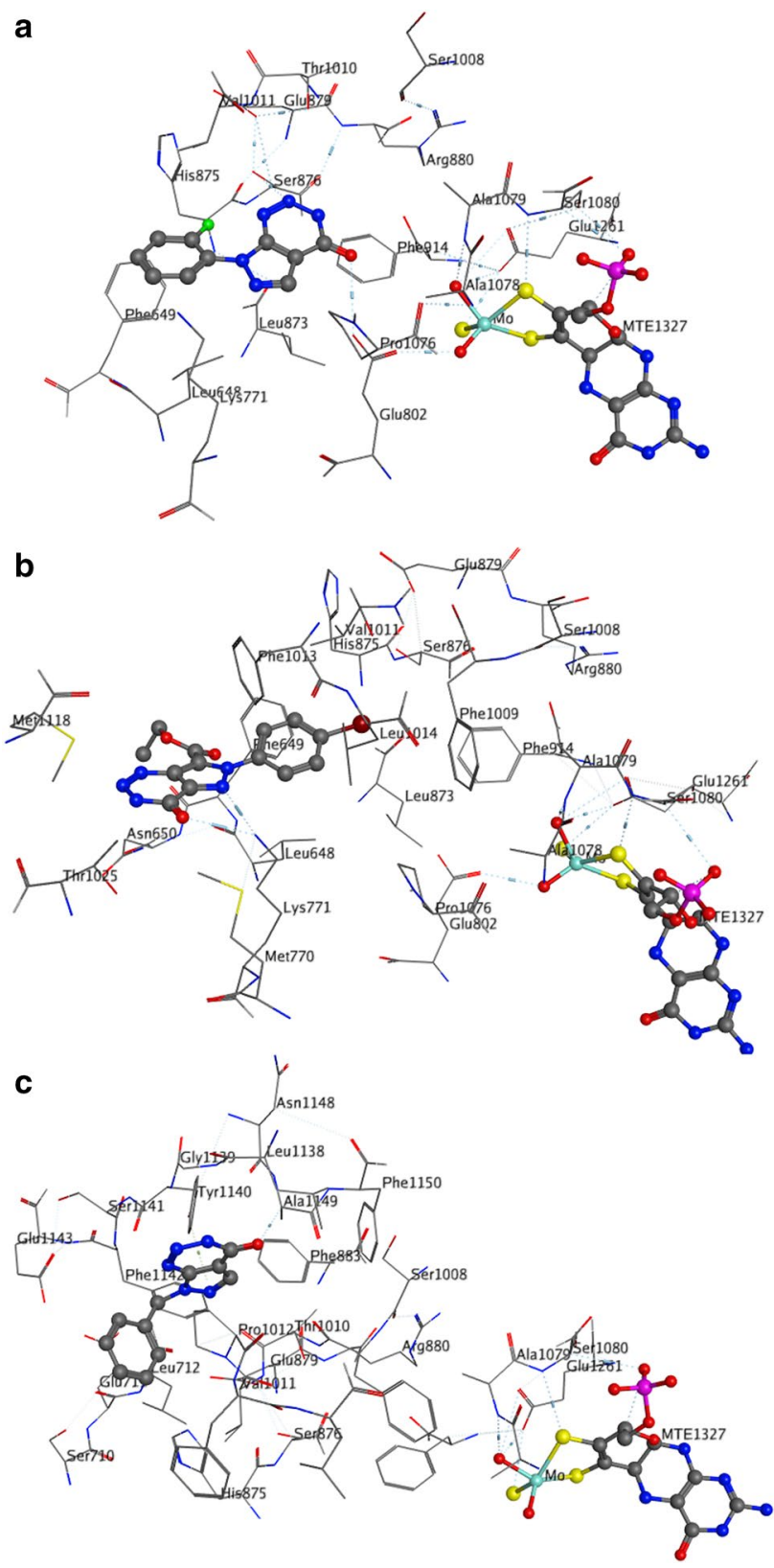

Fig. 3 Binding sites of PT compounds docked to XO (3NVY). Three subsites were found: a Subsite 1 that includes PT $\mathbf{2 e}$ (detailed in rods); $\mathbf{b}$ Subsite 2 in that is shown PT 3e, c Subsite 3 in which is detailed in rods one of the PT compound $(\mathbf{2 g})$ belonging to it

It has been reported that interactions with residues Glu802, Arg880 and Glu1261 are essential for the catalytic reaction [14]. Figure 4 shows a $2 \mathrm{D}$ graphic description of the ligand interactions for the most active of each series. For $\mathbf{2 e}$, it was observed a hydrogen binding with Glu802 residue, which was reported as essential for enzymatic catalysis, playing a key role in the hydroxylation of the substrate [15]. For its part, $\mathbf{3 c}$ presented a $\pi$-cation interaction with Tyr 1140 residue that contributed to an important binding affinity for this compound [15].

A correlation between the binding energy of ligands, estimated through the scoring functions LondondG and GBWSA (rescoring), make evident a correlation between the scored values and the biological activity (Fig. 5).

\subsection{Structure activity relationship (SAR)}

A qualitative SAR study was performed using the MOE SAR tool according to previously described [16]. The SAR procedure proved the samples in three scaffolds (Fig. 6). One of them is those of Allopurinol (data not shown). The second and third scaffolds are the common substructure of PTs 2 and PTs 3 respectively.

With reference to $\mathbf{2 e}$ (the most active synthesized PT compounds) a plot of the relative similarities and activities for all PT derivatives in the dataset, compared with PT 2e was performed (Fig. 7). PTs that presented higher activity than $\mathbf{2 e}$ are plotted above the vertically bisecting line, while those with lower activity are plotted below. Only Allopurinol (that was placed above and to the right) resulted more active than $\mathbf{2 e}$. All the rest of PT compounds were placed below.

The most interesting graphic information could be found in the two inferior quadrants. To the left of the horizontal divider are plotted PT $\mathbf{2}$ compounds, which have the same scaffold as $\mathbf{2 e}$. The distance to the left is proportional to the dissimilarity of the R-group substituents (Fig. 6). To the right are plotted the compounds that present different scaffolds (PTs $\mathbf{3}$ ). The distance between dots is proportional to the scaffold dissimilarity itself if both are assigned or the whole molecule otherwise. The similarity was computed using MACCS fingerprints. Allopurinol is located in the above right quadrant and was classified by the SAR as the first scaffold (data not shown).

In summary, the common scaffolds founded for PT 2 series seems to be more prominent than that of the PT $\mathbf{3}$ series. That information turns out to have great potential, and will be taken into account in future synthesis of structurally related compounds.

\section{2D QSAR model}

Quantitative structure-activity relationship (QSAR) models are widely used to describe a biological activity with molecular descriptors. In this work, we have developed a QSAR 2D model, which allows designing and predicting the XO inhibitory activity of new PT derivatives in silico using $\mathrm{MOE}^{\mathrm{TM}}$ 2105.10. software ("Molecular Operating Environment (MOE) 2015.10"). 


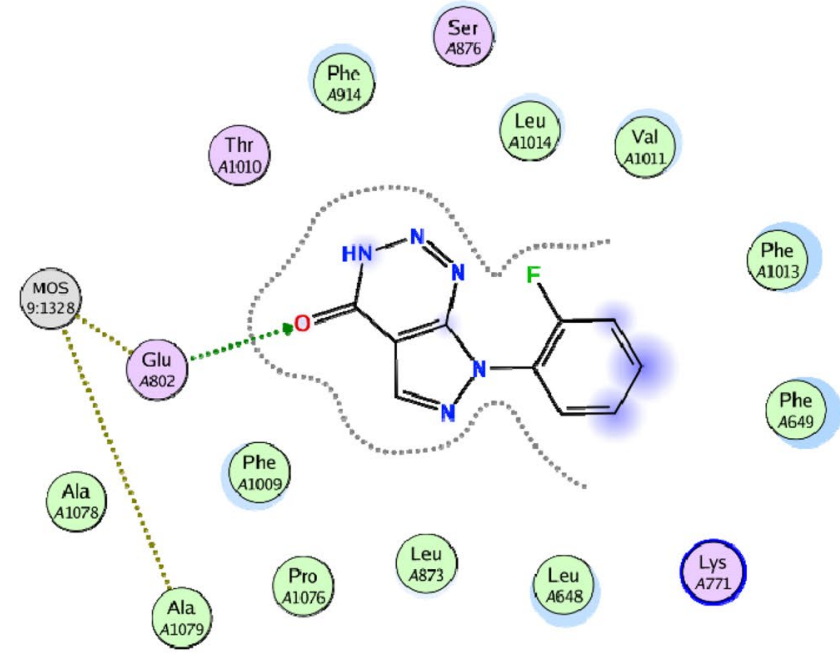

$2 e$

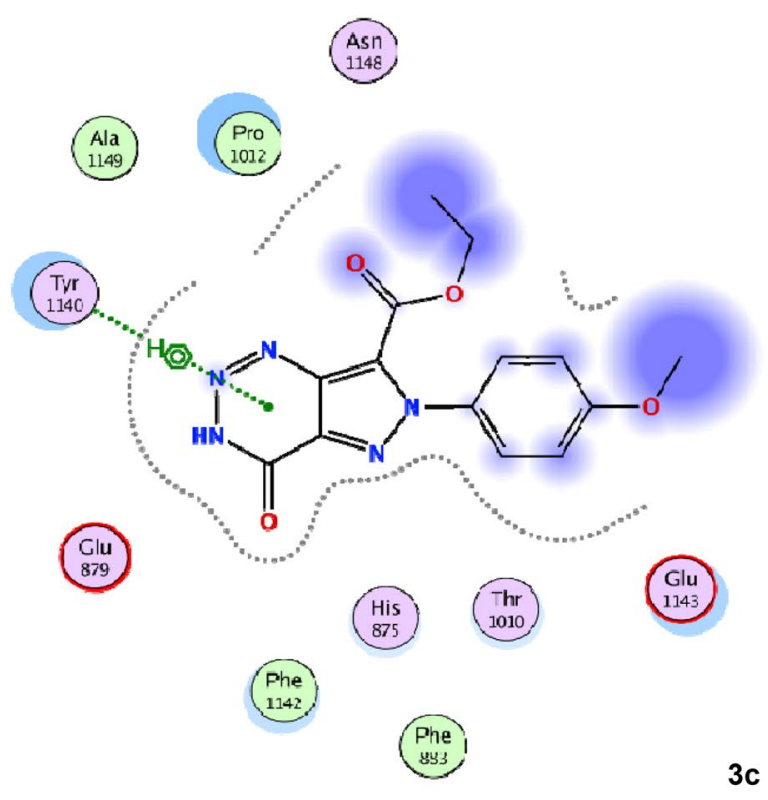

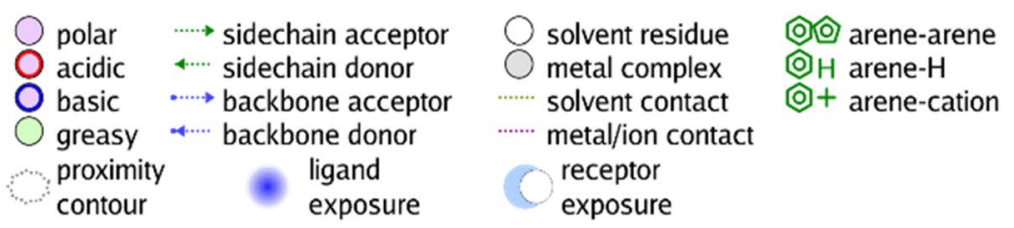

Fig. 4 Ligand interaction of $\mathbf{2 e}$ and $\mathbf{3 c}$ compounds and residues of the active site of xanthine oxidase (3NVY)

Fig. 5 Correlation between the docking scoring and the measured biological activity (- $\log ($ IC50)) with a resulting coefficient of determination $\left(R^{2}\right)$ of 0.76

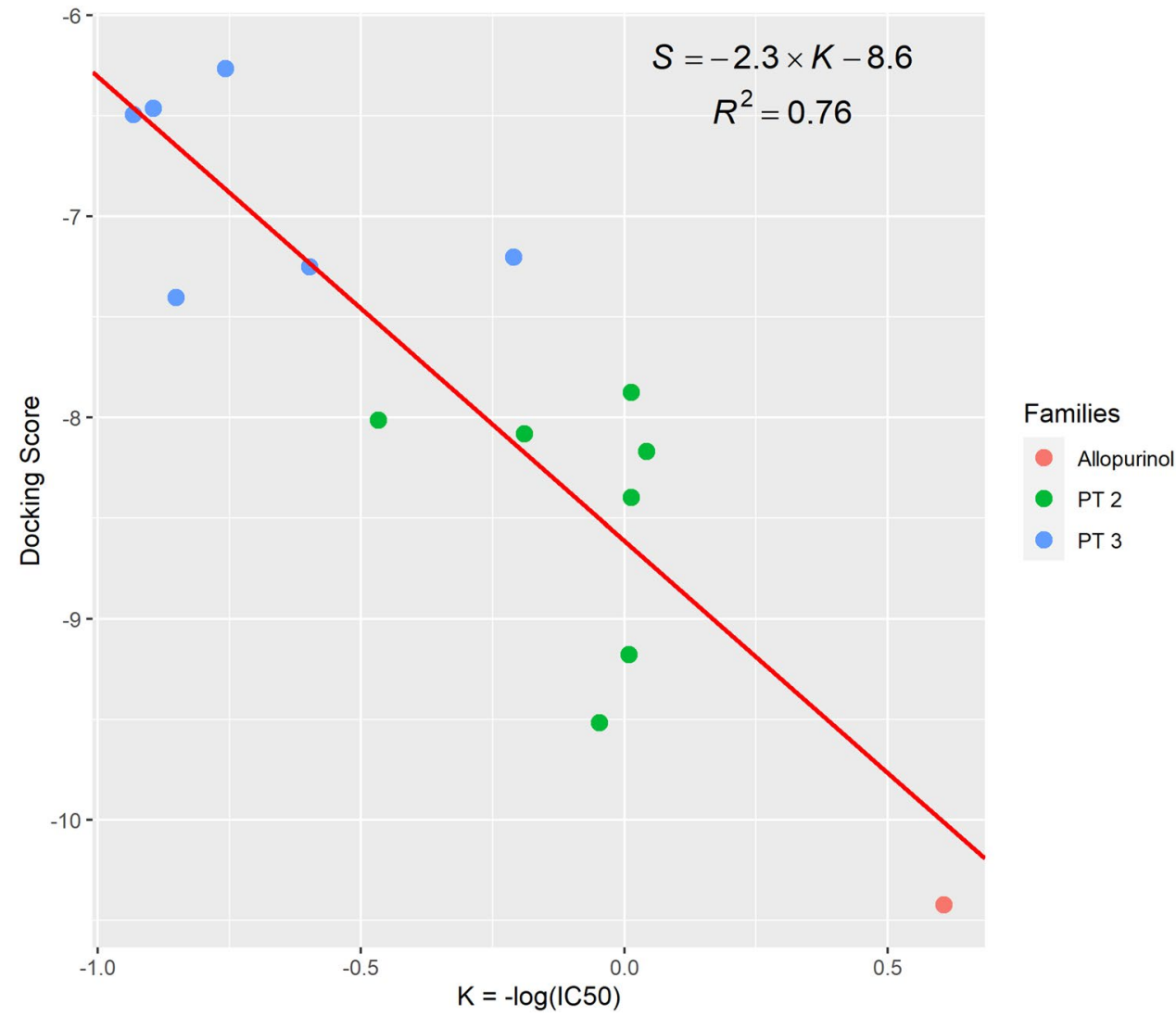

SN Applied Sciences 


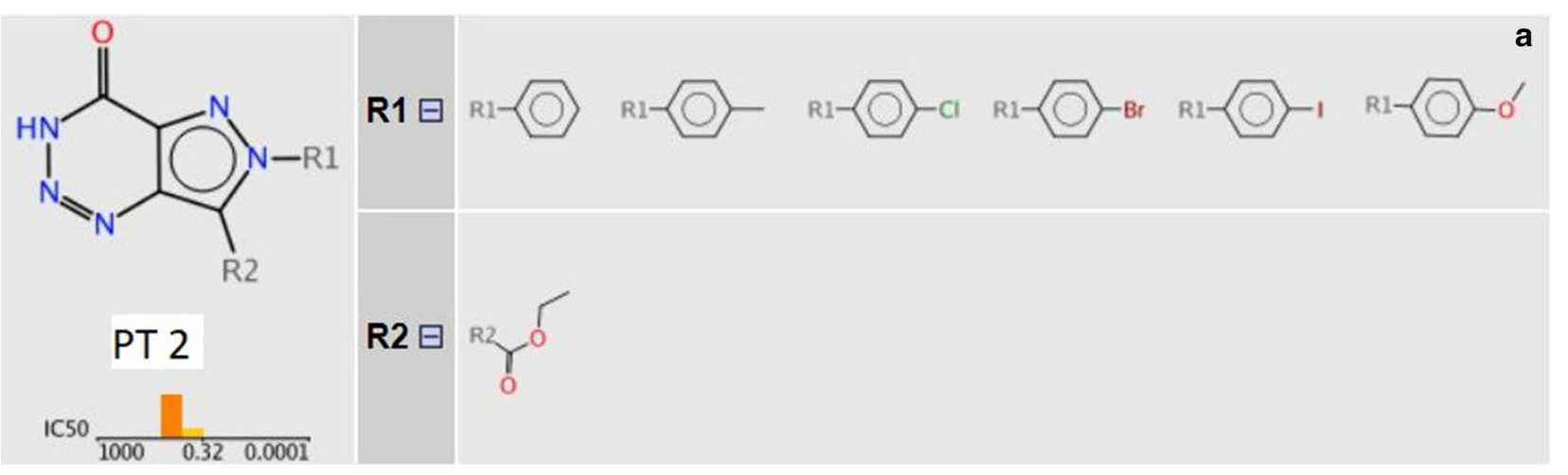<smiles>[R2]n1ncc2c(=O)[nH]nnc21</smiles>

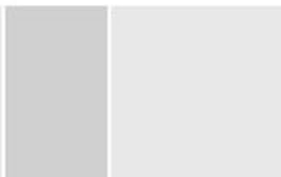

b

R2 $\mathrm{E}$
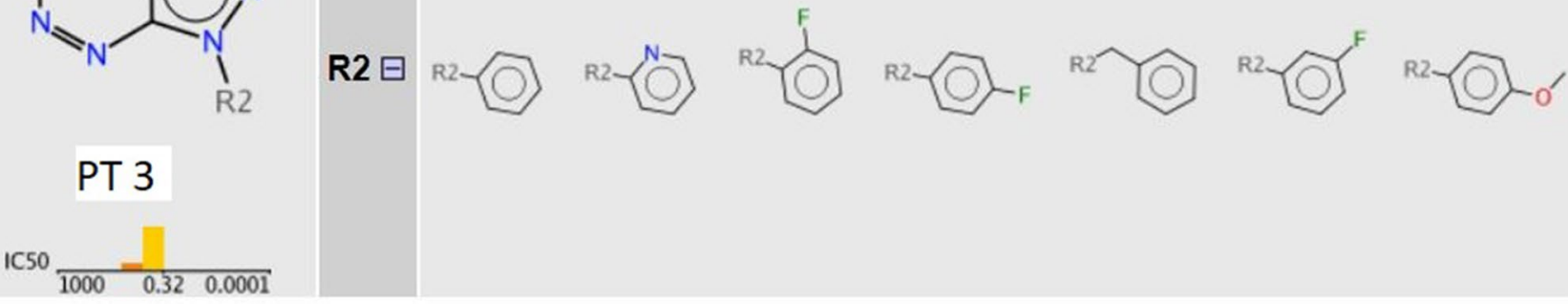

Fig. 6 Three scaffolds were indentified by SAR analysis where one of them is Allopurinol (data not shown). a The second scaffold identified inside the PTs 2, with 7 subsituents that are despicted as R2;

First, several 2D molecular descriptors related to physical properties, van der Waals accessible areas, pharmacophore feature descriptors, partial charge and, 3D molecular descriptors as potential energy, electronic properties, surface area, volume and shape, conformation dependent charge descriptors, were calculated. Subsequently, the QSAR model was derived by partial least squares (PLS) method. We found that the descriptors mostly correlated with bioactivity were, $\log S$ [ $\log$ of the aqueous solubility (mol/L)], AM1_IP [ionization potential ( $\mathrm{kcal} / \mathrm{mol})$ calculated using the AM1 Hamiltonian (MOPAC)] and, E_sol [solvation energy]. The best model by PLS method showed a significant correlation with the bioactivity defined as $\mathrm{K}=-\log \mathrm{IC}_{50}=\mathrm{pIC}_{50}$, with an $\mathrm{R}^{2}$ value of 0.85 and a root mean square error (RMSE) value of 0.17 . The linear model and normalized linear model obtained are shown below:

\begin{tabular}{ll}
\hline Linear model & $\begin{array}{l}\text { Normalized linear model } \\
(\mathrm{SD}=\text { standard deviation) }\end{array}$ \\
\hline $\mathrm{K}=6.5878$ & $\mathrm{~K} / \mathrm{SD}(\mathrm{K})=15.00842$ \\
$-0.612 \times \mathrm{AM} 1 \_\mathrm{IP}$ & $-0.259 \times \mathrm{AM} 1 \_\mathrm{IP}$ \\
$-0.00846 \times \mathrm{E}$ _sol & $-0.06930 \times \mathrm{E}$ sol \\
$+0.40759 \times \operatorname{logS}$ & $+0.78015 \times \operatorname{logS}$ \\
\hline
\end{tabular}

b the third scaffold identified inside the PTs 3, with 6 substituents despicted as R1. In that scaffold a second substituent was identified and named as R2

The linear model obtained was validated with leave-oneout (LOO) cross-validation method. In which, a data point is removed from the set and the model is recalculated. Predicted activity for that point is then compared to its experimental value. The correlation plot between the predicted and the experimental $\mathrm{K}$ values are displayed in Fig. 8.

From this model, it was observed that logS (log of the aqueous solubility), was positively correlated to $\mathrm{K}\left(\mathrm{plC}_{50}\right)$, but E_sol (solvation energy) and, AM1_IP (ionization potential) were negatively correlated to $\mathrm{K}$. Therefore, high values of LogS generate higher XO inhibitory activity that is in accordance with the fact of low E_sol values increase the activity, so high hydrophilicity of molecules improves the XO inhibitory activity.

The high correlation observed demonstrate that the obtained linear model describes the bioactivity-molecular descriptors relationship and would be used to predict the XO inhibitory activity of different PT derivatives. 


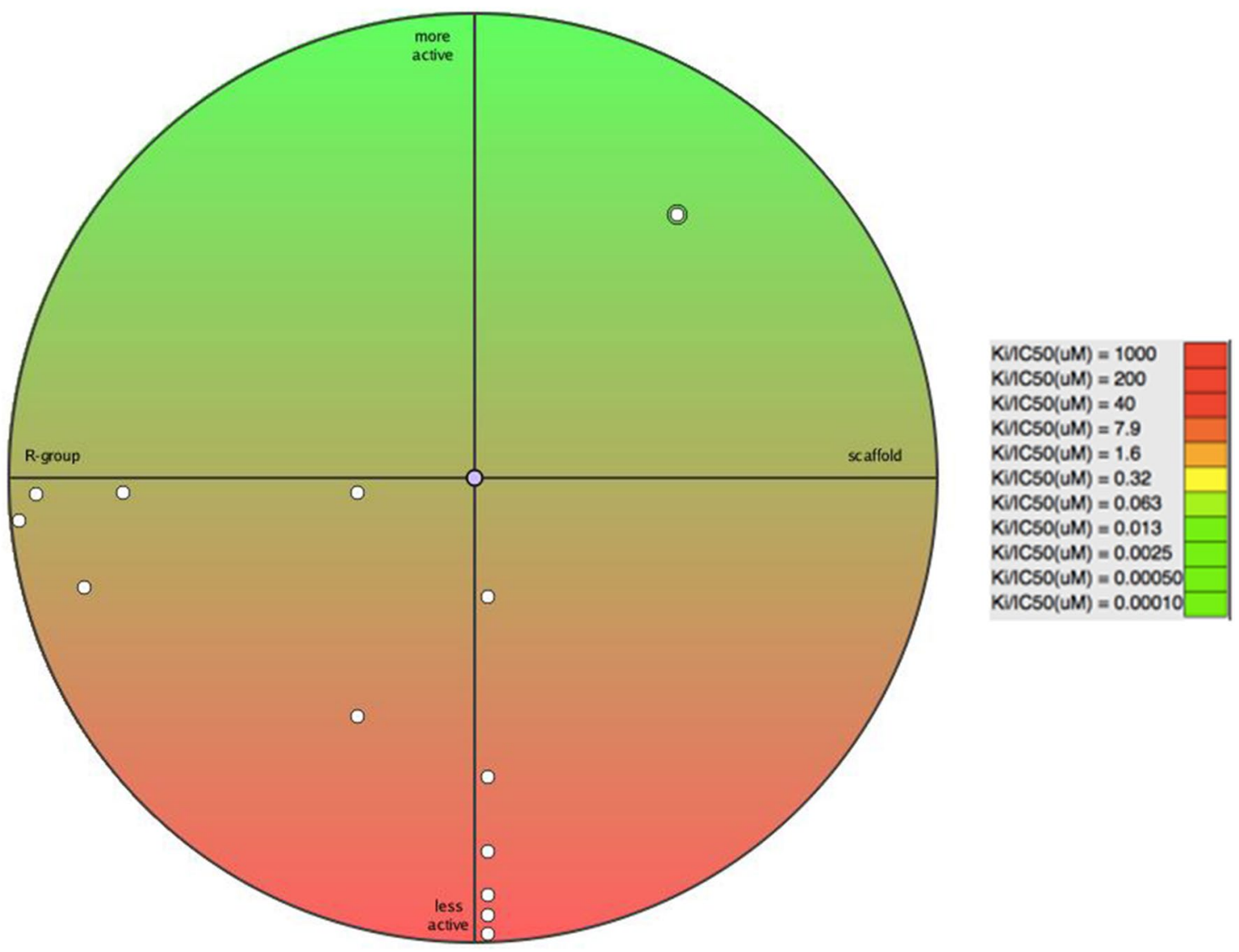

Fig. 7 Plot of activities expressed as $\left.\mathrm{IC}_{50} / \mu \mathrm{M}\right)$. Color coded: green (values of $\mathrm{IC}_{50}$ around $0.0001 \mu \mathrm{M}$ ), to red (values of $\mathrm{IC}_{50}$ around $1000 \mu \mathrm{M})$. Compound $\mathbf{2 e}$ was positioned at the center of the crosshairs. Other PT compounds were plotted, above or below of the current 2e (plot in the center), depending on whether the activ- ity is greater or less. Compounds plotted to the left have the same scaffold and were in correspond to the other PT compounds of the series 2. PT compounds plotted to the right are those of the series $\mathbf{3}$ and have shown a different scaffold

\section{3D QSAR model}

CoMFA (comparative molecular field analysis) in Open3DQsar software was performed to study the correlation between the XO inhibitory activities of PT derivatives and, the steric and electrostatic potentials $[17,18]$. To start with, a docking-pose conformation of compounds was adopted and, a rigid-body alignment of molecules was performed $[19,20]$.

In the 3D QSAR study a PLS method was used for the model building, and the resultant model was validated with LOO method for its predictive ability [19-21]. LOO cross-validation was used as an internal validation to determinate the principal components (PC) with the lowest RMSE and the highest cross-validated coefficient $\mathrm{q}^{2}$. Both of those parameters were calculated with the following equations:

$$
R M S E=\sqrt{\frac{\sum_{i}\left(y_{i}-\hat{y}_{i}\right)^{2}}{n}} \quad q^{2}=1-\frac{\sum_{i}\left(y_{i}-\hat{y}_{i}\right)^{2}}{\sum_{i}\left(y_{i}-\bar{y}\right)^{2}}
$$

whereas $y_{i}$ is the experimental $I C_{50}$ value of $i$ compound, $\hat{y}_{i}$ is the predicted $I C_{50}$ value of $\mathrm{i}$ compound, $\bar{y}$ is the experimental media of the $\mathrm{IC}_{50}$ values of all evaluated compounds $[19,20]$.

The statistic parameters are reported in Table 2. High $\mathrm{q}^{2}$ $\left(q^{2}>0.5\right)$ value is indicate of a good predictive ability of de built model [20]. The model that we presented was built with three principal components that minimizes RMSE values and maximizes the predictive potential of $q^{2}$.

In Fig. 9, is shown the correlation plot between experimental and predicted $\mathrm{K}$ value, with a high-predicted correlation coefficient $R^{2}$ value of 0.86 . This analysis revealed that the proposed CoMFA model could be used to predict $\mathrm{XO}$ inhibitory activity. 
Fig. 8 Correlation plot between predicted vs experimental $K$ value with the QSAR 2D model. Red point corresponds to allopurinol, green and blue points corresponded to PT compounds $\mathbf{2}$ and $\mathbf{3}$

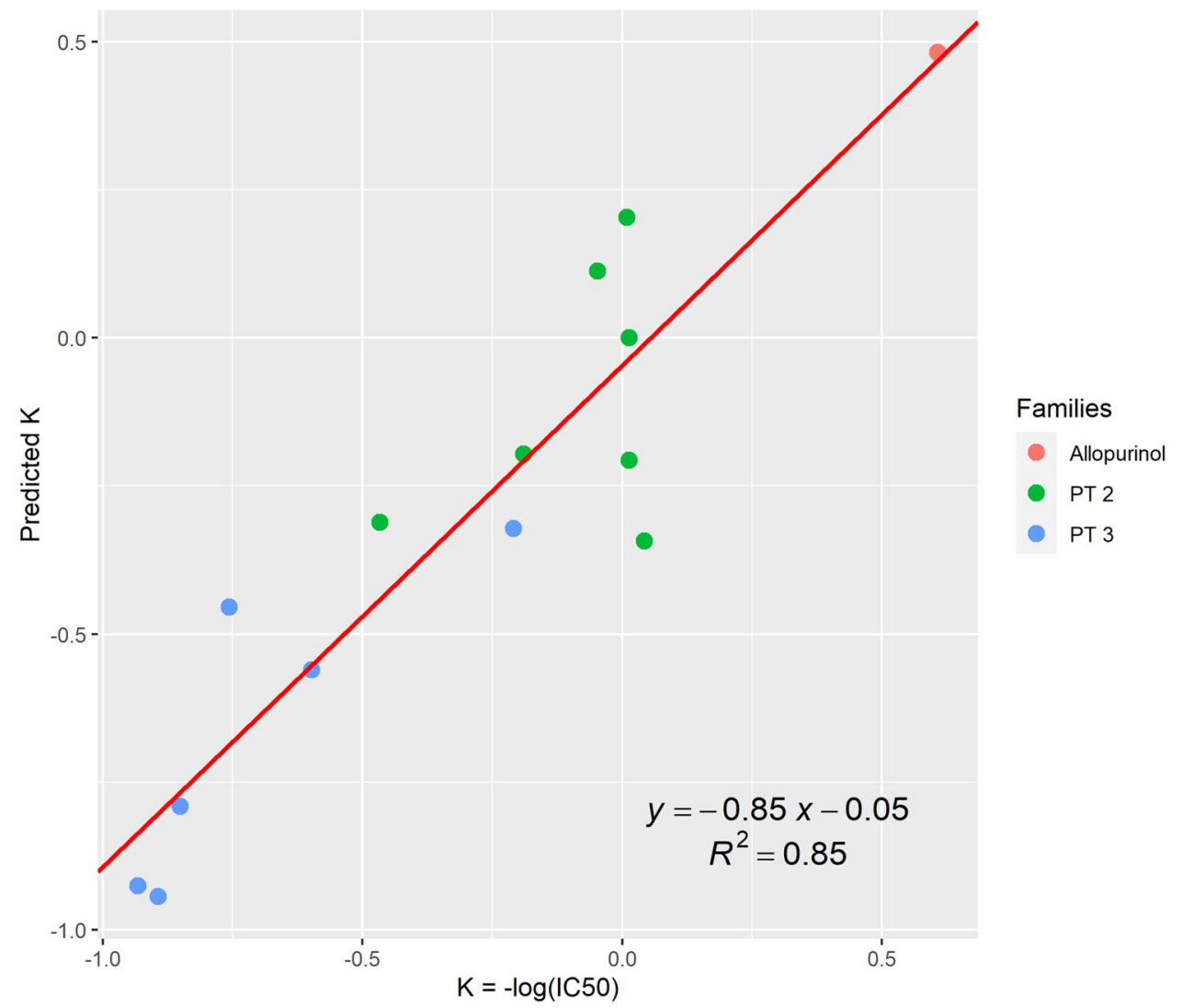

Regarding the electrostatic contours, as it is depicted in Fig. 11, the blue contours represent regions where neutral or positive charges are favorable to the activity; while in red regions the presence of negative charged substituents are promising. The most active compounds of each PT series, $\mathbf{2 e}$ and $\mathbf{3 c}$ present, at least partially, the steric and electrostatic requirements, although this model would lead to the possibility of carrying out a rational design and synthesis of new compounds with increased activity that the PT studied until this point.

\section{Materials and methods}

\subsection{Chemistry}

All reagents were obtained from commercial sources and used without further purification. Proton $\left({ }^{1} \mathrm{H}\right)$ and carbon $\left({ }^{13} \mathrm{C}\right)$ NMR spectra were recorded on a $400 \mathrm{MHz}$ Bruker spectrometer $\left({ }^{1} \mathrm{H}\right.$ at $400.16 \mathrm{MHz}$ and ${ }^{13} \mathrm{C}$ at $100.9 \mathrm{MHz}$ ) at ambient temperature. Solutions were typically prepared in either deuterochloroform $\left(\mathrm{CDCl}_{3}\right)$, deuteroacetone $\left(\left(\mathrm{CD}_{3}\right)_{2} \mathrm{CO}\right)$, deuterated acetonitrile $\left(\mathrm{CD}_{3} \mathrm{CN}\right)$ or deuterated dimethylsulfoxide $\left(\left(\mathrm{CD}_{3}\right)_{2} \mathrm{SO}\right)$ with chemical shifts referenced to deuterated solvent as an internal standard. ${ }^{1} \mathrm{H}$ NMR data are reported indicating the chemical shift $(\delta)$,
The steric contour maps of the CoMFA model are shown in Fig. 10. The yellow contours represent regions where bulky substituents would decrease the $\mathrm{XO}$ inhibitory activity, while the green contours represent regions where the steric bulky groups would be favorable. Those facts could explain the differences in the activity of each PT series, as it can be observed in Fig. 10a, b. 
Fig. 9 Plot of predicted versus experimental $\mathrm{K}$ value by CoMFA. Red point corresponds to allopurinol, green and blue points corresponded to PT derivatives $\mathbf{2}$ and $\mathbf{3}$

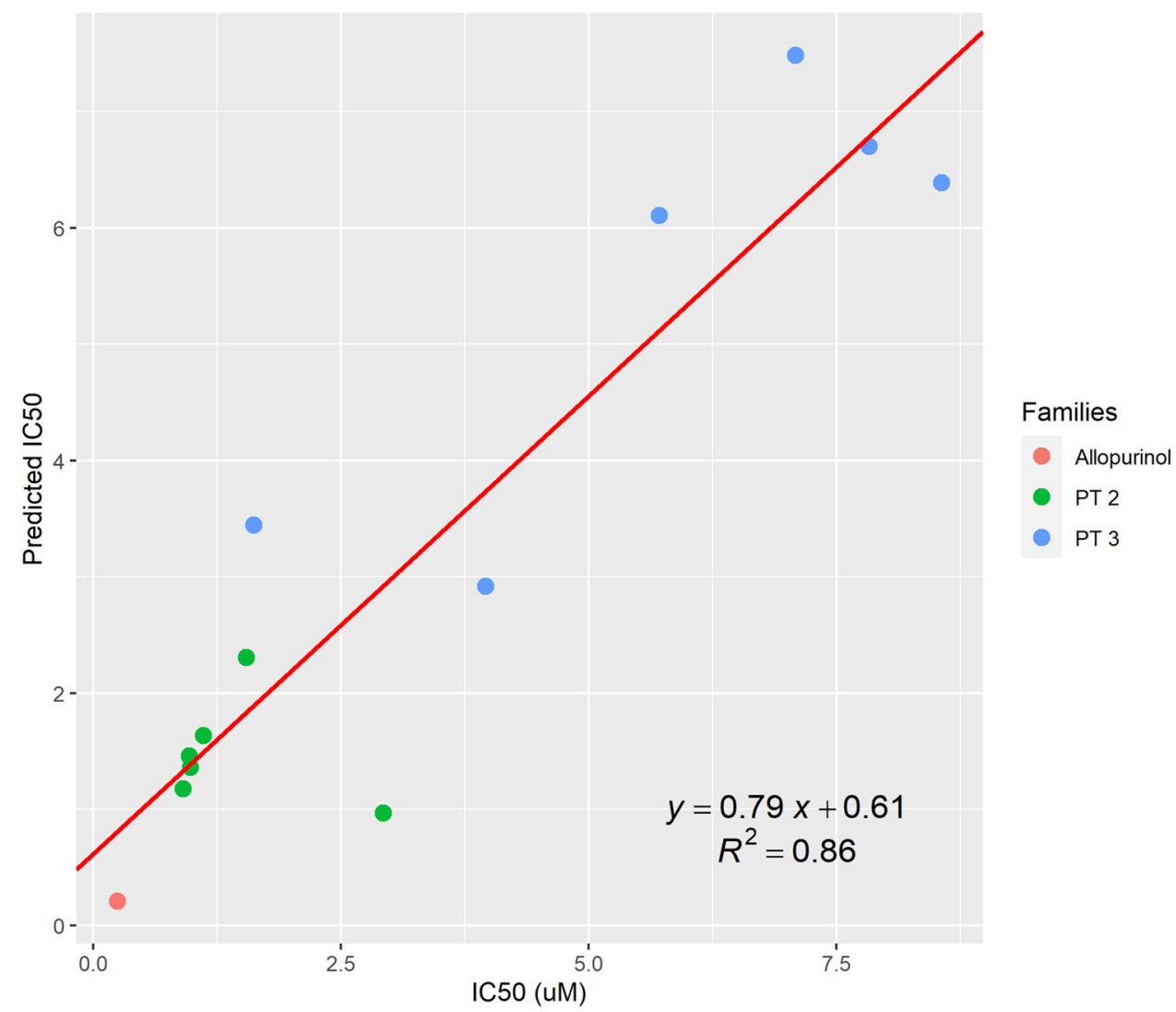

b

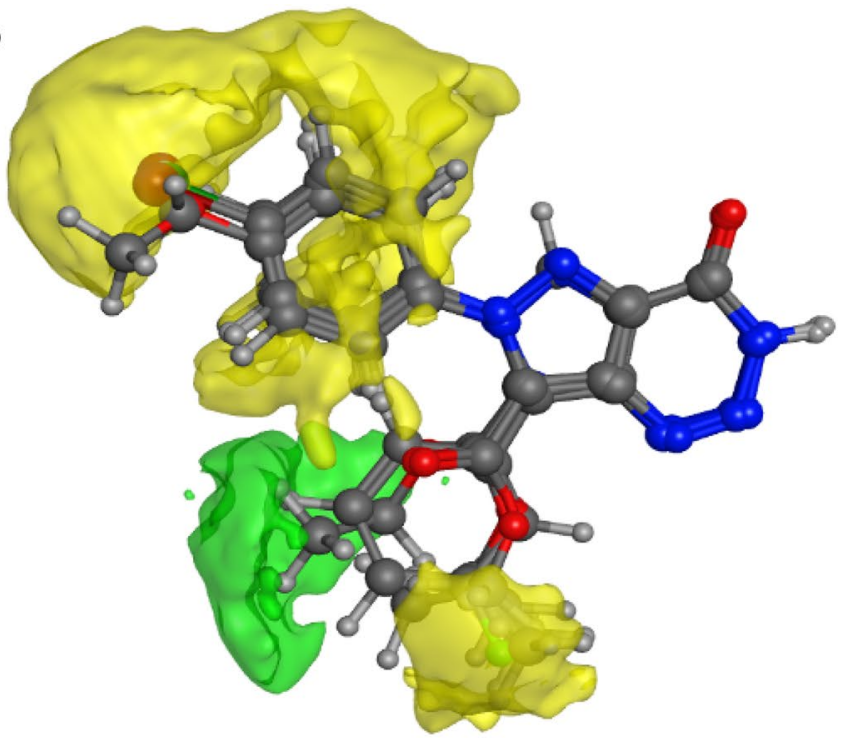

Fig. 10 Steric contour maps for a allopurinol and the most active compounds of PT series $\mathbf{2}$ (2e, 2a, 2b, 2c, 2e, $\mathbf{2 g}$ and $\mathbf{2 f}$ ); $\mathbf{b}$ allopurinol and, all PT compounds. Yellow contours: regions where bulky substituents would decrease the XO inhibitory activity; green contours: regions where the steric bulky groups would be favorable 


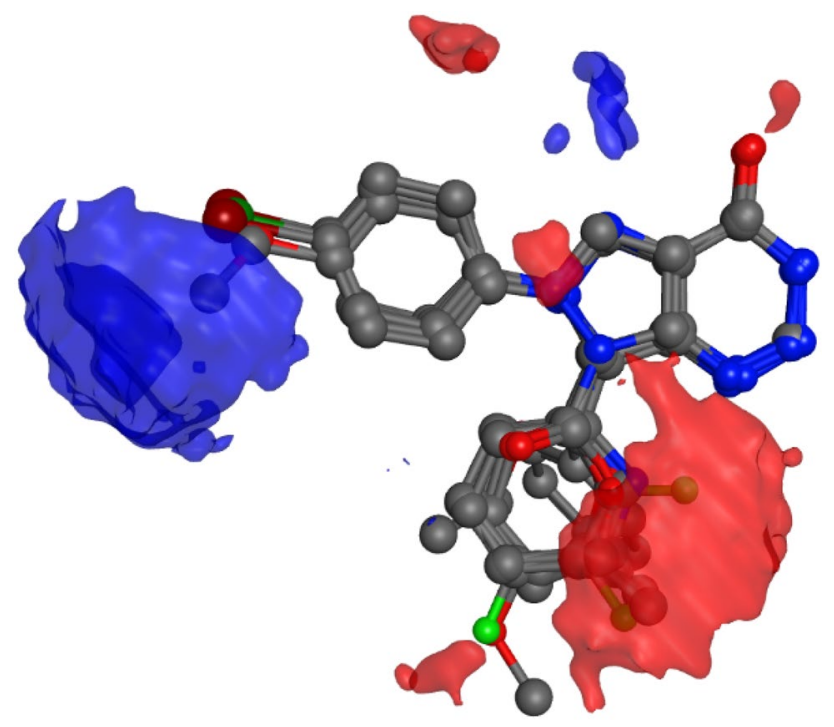

Fig. 11 Electrostatic contour maps for allopurinol and all PT derivatives. Blue contours: regions where neutral or positive charges are favorable to the activity; red regions: negative charged substituents are promising to inhibitory activity

the multiplicity (s, singlet; $d$, doublet; $t$, triplet; q, quartet; $\mathrm{m}$, multiplet), the coupling constant $(\mathrm{J})$ in $\mathrm{Hz}$ and the integration (e.g. $\left.{ }^{1} \mathrm{H}\right)$. High resolution mass spectra (HRMS) were recorded on a LC-MS Bruker Daltonics Micro TOFF QII with electrospray ionization (ESI) and Q-TOF detection.

\subsection{General procedure for the synthesis of pyra- zolotriazines}

Aqueous $\mathrm{NaNO}_{2}(1 \mathrm{~mL}, 1.8 \mathrm{mmol})$ was added to a stirred and cooled solution $\left(0-5{ }^{\circ} \mathrm{C}\right)$ of pyrazole precursors $(\mathbf{1}, 1$ $\mathrm{mmol}$ ) in a mixture of $\mathrm{HCl}: \mathrm{AcOH}(3: 1,20 \mathrm{~mL})$ over a period of $10 \mathrm{~min}[11,12]$. The reaction mixture was allowed to warm at room temperature and was stirred for $20 \mathrm{~h}$. The precipitate of pyrazolotriazine ( $\mathbf{2}$ or $\mathbf{3}$ ) obtained was filtered off, and the residue was diluted with water $(20 \mathrm{~mL})$. After that, the solution was extracted with dichloromethane $(3 \times 20 \mathrm{~mL})$ and the organic phase was dried with anhydrous $\mathrm{MgSO}_{4}$. The resulting solution was concentrated to dryness, and the solid was then subject to chromatographic column separation with dichloromethane and dichloromethane/ethyl acetate in different proportions.

The spectral characteristics of compounds $\mathbf{2} \mathbf{a}-\mathbf{g}$ corresponded to literature values [11, 12].

\subsubsection{7-Phenyl-3H-pyrazolo[3,4-d][1-3]triazin-4(7H)-one} (2a)

This compound was obtained as white crystals after column chromatography, $77 \%$ yield; mp $137.1^{\circ} \mathrm{C}$ (dec.). ${ }^{1} \mathrm{H}$
NMR (400 MHz, $\left.\mathrm{CD}_{3} \mathrm{CN}, 25^{\circ} \mathrm{C}\right): \delta=7.51(\mathrm{t}, J=7.0 \mathrm{~Hz}, 1 \mathrm{H})$, $7.62(\mathrm{t}, J=7.4 \mathrm{~Hz}, 2 \mathrm{H}), 8.06(\mathrm{~d}, J=7.8 \mathrm{~Hz}, 1 \mathrm{H}), 8.36(\mathrm{~s}, 1$ $\mathrm{H}), 12.85(\mathrm{~s}, 1 \mathrm{H}) \mathrm{ppm} .{ }^{13} \mathrm{C}$ NMR $\left(101 \mathrm{MHz}, \mathrm{CDCl}_{3}, 25^{\circ} \mathrm{C}\right)$ : $\delta=108.1,122.8,128.8,129.7,135.4,137.9,147.9,154.0$. HRMS $\left(\right.$ ESI $\left.^{+}\right)$: calcd. For $\mathrm{C}_{10} \mathrm{H}_{8} \mathrm{~N}_{5} \mathrm{O}^{+} 214.0729$; found 214.0724.

\subsubsection{7-(4-Methoxyphenyl)-3H-pyrazolo[3,4-d][1-3] triazin-4(7H)-one (2b)}

This compound was obtained as an orange powder, $88 \%$ yield; mp $150.4{ }^{\circ} \mathrm{C}$ (dec.). ${ }^{1} \mathrm{H}$ NMR $\left(400 \mathrm{MHz},\left(\mathrm{CD}_{3}\right)_{2} \mathrm{SO}\right.$, $\left.25^{\circ} \mathrm{C}\right): \delta=3.85(\mathrm{~s}, 3 \mathrm{H}), 7.18\left(\mathrm{~d}, J_{\text {orto }}=9.0 \mathrm{~Hz}, 2 \mathrm{H}\right), 7.92(\mathrm{~d}$, $\left.J_{\text {orto }}=9.0 \mathrm{~Hz}, 2 \mathrm{H}\right), 8.56(\mathrm{~s}, 1 \mathrm{H}), 15.24$ (br. signal, $\left.1 \mathrm{H}\right) \mathrm{ppm}$. ${ }^{13} \mathrm{C}$ NMR $\left(101 \mathrm{MHz},\left(\mathrm{CD}_{3}\right)_{2} \mathrm{SO}, 25^{\circ} \mathrm{C}\right): \delta=55.6,107.2,114.6$, 124.4, 130.5, 134.9, 147.7, 153.8, 159.1 ppm. HRMS (ESI ${ }^{+}$: calcd. For $\mathrm{C}_{11} \mathrm{H}_{10} \mathrm{~N}_{5} \mathrm{O}_{2}{ }^{+}$244.0835; found 244.0832.

\subsubsection{7-(4-Fluorophenyl)-3H-pyrazolo[3,4-d][1-3]tria- zin-(7H)-one (2c)}

This derivative was obtained as a white power after columnchromatography, $70 \%$ yield; $\mathrm{mp} 153.7^{\circ} \mathrm{C}$ (dec.). ${ }^{1} \mathrm{H}$ NMR $\left(400 \mathrm{MHz},\left(\mathrm{CD}_{3}\right)_{2} \mathrm{CO}, 25^{\circ} \mathrm{C}\right): \delta=7.43(\mathrm{~m}, 2 \mathrm{H}), 8.20(\mathrm{~m}, 2 \mathrm{H})$, $8.43(\mathrm{~s}, 1 \mathrm{H}), 14.02$ (br. signal, $1 \mathrm{H}) \mathrm{ppm} .{ }^{13} \mathrm{C}$ NMR $(101 \mathrm{MHz}$, $\left.\left(\mathrm{CD}_{3}\right)_{2} \mathrm{CO}, 25^{\circ} \mathrm{C}\right): \delta=108.1,116.3,116.5,125.0,125.1,134.7$, 134.7, 135.2, 148.6, 154.2, 161.1, 163.6 ppm. HRMS (ESI ${ }^{+}$): calcd. for $\mathrm{C}_{10} \mathrm{H}_{7} \mathrm{FN}_{5} \mathrm{O}^{+}$232.0635; found 232.0633.

\subsubsection{7-(3-Fluorophenyl)-3H-pyrazolo[3,4-d][1-3]tria- zin-4(7H)-one (2d)}

This compound was obtained as a white powder, $52 \%$ yield, mp $148.1{ }^{\circ} \mathrm{C}$ (dec.). ${ }^{1} \mathrm{H}$ NMR $\left(400 \mathrm{MHz},\left(\mathrm{CD}_{3}\right)_{2} \mathrm{SO}, 25\right.$ $\left.{ }^{\circ} \mathrm{C}\right): \delta=15.39(\mathrm{~s}, 1 \mathrm{H}), 8.65(\mathrm{~s}, 1 \mathrm{H}),, 8.00-7.93(\mathrm{~m}, 2 \mathrm{H}), 7.70$ (dt, $J=8.3,6.6 \mathrm{~Hz}, 1 \mathrm{H}), 7.38$ (tdd, $J=8.5,2.5,0.8 \mathrm{~Hz}, 1 \mathrm{H}$ ) ppm. ${ }^{13} \mathrm{C}$ NMR $\left(101 \mathrm{MHz},\left(\mathrm{CD}_{3}\right){ }_{2} \mathrm{SO}, 25^{\circ} \mathrm{C}\right): \delta=162.1(\mathrm{~d}$, $J=244.5 \mathrm{~Hz}), 153.7,148.3,138.8(\mathrm{~d}, J=10.7 \mathrm{~Hz}), 135.8$, $131.5(\mathrm{~d}, J=9.1 \mathrm{~Hz}), 118.3(\mathrm{~d}, J=3.0 \mathrm{~Hz}), 115.1(\mathrm{~d}, J=20.9$ $\mathrm{Hz}), 109.7(\mathrm{~d}, J=26.6 \mathrm{~Hz}), 108.1 \mathrm{ppm}$. HRMS calculated for $\mathrm{C}_{10} \mathrm{H}_{7} \mathrm{~N}_{5} \mathrm{OFH}^{+}$232.06291; found 232.06279.

\subsubsection{7-(2-Fluorophenyl)-3H-pyrazolo[3,4-d][1-3]tria- zin-4(7H)-one (2e)}

This compound was obtained as a white powder after column chromatography, $64 \%$ yield; $\mathrm{mp} 145.2^{\circ} \mathrm{C}$ (dec.). ${ }^{1} \mathrm{H}$ NMR $\left(400 \mathrm{MHz},\left(\mathrm{CD}_{3}\right)_{2} \mathrm{SO}, 25^{\circ} \mathrm{C}\right): \delta=7.49$ (td, $J_{\text {orto }}=7.3$ $\left.\mathrm{Hz}, J_{\text {meta }}=0.9 \mathrm{~Hz}, 1 \mathrm{H}\right), 7.57-7.62(\mathrm{~m}, 1 \mathrm{H}), 7.67-7.73(\mathrm{~m}, 1$ $\mathrm{H}), 7.79\left(\mathrm{td}, J_{\text {orto }}=7.8 \mathrm{~Hz}, J_{\text {meta }}=1.7 \mathrm{~Hz}, 1 \mathrm{H}\right), 8.68(\mathrm{~s}, 1 \mathrm{H})$, 15.32 (br. Signal, $1 \mathrm{H})$ ppm. ${ }^{13} \mathrm{C} \mathrm{NMR}\left(101 \mathrm{MHz},\left(\mathrm{CD}_{3}\right)_{2} \mathrm{SO}\right.$, $\left.25^{\circ} \mathrm{C}\right): \delta=106.9,116.98\left(J_{C \beta-F}=19.5 \mathrm{~Hz}\right), 124.3\left(J_{C \beta-F}=11,4\right.$ 
$\mathrm{Hz}), 125.4\left(J_{C \gamma-F}=4.0 \mathrm{~Hz}\right), 128.9,132.1\left(J_{C \gamma-F}=8.1 \mathrm{~Hz}\right), 136.2$, 149.0, 153.7, $155.9\left(J_{C a-F}=252.4 \mathrm{~Hz}\right)$ ppm. HRMS $\left(\mathrm{ESI}^{+}\right)$: calcd. for $\mathrm{C}_{10} \mathrm{H}_{7} \mathrm{~N}_{5} \mathrm{OF}^{+} 232.0635$; found 232.0631.

\subsubsection{7-(Pyridin-2-yl)-3H-pyrazolo[3,4-d][1-3]tria- zin-4(7H)-one (2f)}

This compound was obtained as yellow crystals, $39 \%$ yield; mp $157.5^{\circ} \mathrm{C}$ (dec.). ${ }^{1} \mathrm{H}$ NMR $\left(400 \mathrm{MHz},\left(\mathrm{CD}_{3}\right)_{2} \mathrm{SO}, 25^{\circ} \mathrm{C}\right)$ : $\delta=8.64(\mathrm{ddd}, J=4.8,1.8,0.7 \mathrm{~Hz}, 1 \mathrm{H}), 8.49(\mathrm{~s}, 1 \mathrm{H}), 8.14(\mathrm{td}$, $J=7.6,1.9 \mathrm{~Hz}, 1 \mathrm{H}), 7.82(\mathrm{dt}, J=8.2,0.8 \mathrm{~Hz}, 1 \mathrm{H}), 7.63$ (ddd, $J=7.5,4.8,1.0 \mathrm{~Hz}, 1 \mathrm{H}) \mathrm{ppm} .{ }^{13} \mathrm{C} \mathrm{NMR}\left(101 \mathrm{MHz},\left(\mathrm{CD}_{3}\right)_{2} \mathrm{SO}\right.$, $\left.25^{\circ} \mathrm{C}\right): \delta=149.7,148.6,143.4,139.9,133.4,125.0,119.0$, $111.7,94.4 \mathrm{ppm}$.

\subsubsection{7-Benzyl-3H-pyrazolo[3,4-d][1-3]triazin-4(7H)-one} (2g)

The compound was obtained as colorless crystals after column chromatography, 50\% yiled; mp $176.7^{\circ} \mathrm{C}$ (dec.). ${ }^{1} \mathrm{H}$ $\operatorname{NMR}\left(400 \mathrm{MHz},\left(\mathrm{CD}_{3}\right)_{2} \mathrm{SO}, 25^{\circ} \mathrm{C}\right): \delta=5.71(\mathrm{~s}, 2 \mathrm{H}), 7.33-7.48$ $(\mathrm{m}, 5 \mathrm{H}), 8.69(\mathrm{~s}, 1 \mathrm{H}), 13.46(\mathrm{~s}, 1 \mathrm{H}) \mathrm{ppm} .{ }^{13} \mathrm{C}$ NMR $(101$ $\left.\mathrm{MHz},\left(\mathrm{CD}_{3}\right)_{2} \mathrm{SO}, 25^{\circ} \mathrm{C}\right): \delta=58.3,107.7,129.0,129.3,129.4$, $129.7,136.5,154.9,158.2$ ppm. HRMS (ESI+): calcd. for $\mathrm{C}_{11} \mathrm{H}_{10} \mathrm{~N}_{5} \mathrm{O}+228.0885$; found 228.0881 .

\subsubsection{Ethyl 4-oxo-6-phenyl-4,6-dihydro-3H-pyrazolo[4,3-d] [1-3]triazine-7-carboxylate (3a)}

This compound was obtained as a pale yellow solid, 35\% yield; $\mathrm{mp} 156.7^{\circ} \mathrm{C}$ (dec). ${ }^{1} \mathrm{H}$ NMR $\left(400 \mathrm{MHz},\left(\mathrm{CD}_{3}\right)_{2} \mathrm{CO}\right.$, $\left.25^{\circ} \mathrm{C}\right): \delta=13.90(\mathrm{~s}, 1 \mathrm{H}), 7.77-7.54(\mathrm{~m}, 5 \mathrm{H}), 4.38(\mathrm{q}, J=7.1$ $\mathrm{Hz}, 2 \mathrm{H}), 1.27(\mathrm{t}, J=7.1 \mathrm{~Hz}, 3 \mathrm{H}) \mathrm{ppm} .{ }^{13} \mathrm{C}$ NMR $(100 \mathrm{MHz}$, $\left.\left(\mathrm{CD}_{3}\right)_{2} \mathrm{CO}, 25^{\circ} \mathrm{C}\right): \delta=158.2,152.9,140.8,137.4,135.6,131.0$, $130.6,129.9,126.8,63.0,14.2 \mathrm{ppm}$. HRMS calculated for $\mathrm{C}_{13} \mathrm{H}_{11} \mathrm{~N}_{5} \mathrm{O}_{3} \mathrm{Na}^{+}$: 308.0754; found: 308.0760 .

\subsubsection{Ethyl 4-oxo-6-(p-tolyl)-4,6-dihy- dro-3H-pyrazolo[4,3-d][1-3]triazine-7-carboxylate (3b)}

This compound was obtained as a yellow solid, $38 \%$ yield; mp 159.2 (dec). ${ }^{1} \mathrm{H}$ NMR $\left(400 \mathrm{MHz},\left(\mathrm{CD}_{3}\right)_{2} \mathrm{SO}, 25^{\circ} \mathrm{C}\right)$ : $\delta=14.99(\mathrm{~s}, 1 \mathrm{H}), 7.52(\mathrm{~d}, J=8.4 \mathrm{~Hz}, 2 \mathrm{H}), 7.39(\mathrm{~d}, J=8.1 \mathrm{~Hz}$, $2 \mathrm{H}), 4.33(\mathrm{q}, J=7.1 \mathrm{~Hz}, 2 \mathrm{H}), 2.43(\mathrm{~s}, 3 \mathrm{H}), 1.21(\mathrm{t}, J=7.1 \mathrm{~Hz}$, $3 H)$ ppm. ${ }^{13} \mathrm{C}$ NMR $\left(100 \mathrm{MHz},\left(\mathrm{CD}_{3}\right)_{2} \mathrm{SO}, 25^{\circ} \mathrm{C}\right): \delta=157.1$, $152.3,140.1,137.0,136.1,134.0,129.4,128.8,125.7,62.1$, 20.8, 13.8 ppm. HRMS calculated for $\mathrm{C}_{14} \mathrm{H}_{13} \mathrm{~N}_{5} \mathrm{O}_{3} \mathrm{Na}^{+}$: 322.0911; found: 322.0906 .
5.2.10 Ethyl 6-(4-methoxyphenyl)-4-oxo-4,6-dihydro-3H-pyrazolo[4,3-d][1-3]triazine-7-carboxylate (3c)

This compound was obtained as a light brown solid, $28 \%$ yield; $\mathrm{mp} 164.3^{\circ} \mathrm{C}$ (dec). ${ }^{1} \mathrm{H} \mathrm{NMR}\left(400 \mathrm{MHz}, \mathrm{CDCl}_{3}, 25^{\circ} \mathrm{C}\right)$ : $\delta=11.55(\mathrm{~s}, 1 \mathrm{H}), 7.47(\mathrm{~d}, J=8.9 \mathrm{~Hz}, 2 \mathrm{H}), 7.03(\mathrm{~d}, J=8.9 \mathrm{~Hz}$, $2 \mathrm{H}), 4.47(\mathrm{q}, J=7.1 \mathrm{~Hz}, 2 \mathrm{H}), 3.90(\mathrm{~s}, 3 \mathrm{H}), 1.37(\mathrm{t}, J=7.1 \mathrm{~Hz}$, $3 H)$ ppm. ${ }^{13} \mathrm{C}$ NMR $\left(101 \mathrm{MHz}, \mathrm{CDCl}_{3}, 25^{\circ} \mathrm{C}\right): \delta=161.2,158.8$, $157.7,151.9,134.4,132.2,127.1,114.3,109.9,63.0,55.8$, 29.9 ppm. HRMS calculated for $\mathrm{C}_{14} \mathrm{H}_{13} \mathrm{~N}_{5} \mathrm{O}_{4} \mathrm{Na}^{+}$: 338.0806; found: 338.0863 .

\subsubsection{Ethyl 6-(4-chlorophenyl)-4-oxo-4,6-dihy- dro-3H-pyrazolo[4,3-d][1-3]triazine-7-carboxylate (3e)}

This compound was obtained as a pale yellow solid, $31 \%$ yield; mp 172.1 (dec). ${ }^{1} \mathrm{H}$ NMR $\left(400 \mathrm{MHz}, \mathrm{CD}_{3} \mathrm{CN}\right.$, $\left.25^{\circ} \mathrm{C}\right): \delta=12.70(\mathrm{~s}, 1 \mathrm{H}), 7.59(\mathrm{~m}, 4 \mathrm{H}), 4.38(\mathrm{q}, J=7.1$ $\mathrm{Hz}, 2 \mathrm{H}), 1.26(\mathrm{t}, J=7.1 \mathrm{~Hz}, 3 \mathrm{H}) \mathrm{ppm} .{ }^{13} \mathrm{C}$ NMR $(101 \mathrm{MHz}$, $\left.\mathrm{CD}_{3} \mathrm{CN}, 25^{\circ} \mathrm{C}\right): \delta=158.3,153.1,139.4,137.6,136.7,135.8$, $130.8,130.1,128.7,63.6,14.2 \mathrm{ppm}$. HRMS calculated for $\mathrm{C}_{13} \mathrm{H}_{10} \mathrm{ClN}_{5} \mathrm{O}_{3} \mathrm{Na}^{+}: 342.0364$; found: 342.0374 .

\subsubsection{Ethyl 6-(4-bromophenyl)-4-oxo-4,6-dihy- dro-3H-pyrazolo[4,3-d][1-3]triazine-7-carboxylate} (3f)

This compound was obtained as a yellow solid, $36 \%$ yield; $\mathrm{mp} 175.8^{\circ} \mathrm{C}$ (dec). ${ }^{1} \mathrm{H}$ NMR $\left(400 \mathrm{MHz},\left(\mathrm{CD}_{3}\right)_{2} \mathrm{CO}, 25^{\circ} \mathrm{C}\right)$ : $\delta=13.93(\mathrm{~s}, 1 \mathrm{H}), 7.83(\mathrm{~d}, J=8.8 \mathrm{~Hz}, 2 \mathrm{H}), 7.67(\mathrm{~d}, J=8.8 \mathrm{~Hz}$, $2 \mathrm{H}), 4.41(\mathrm{q}, J=7.1 \mathrm{~Hz}, 2 \mathrm{H}), 1.30(\mathrm{t}, J=7.1 \mathrm{~Hz}, 3 \mathrm{H}) \mathrm{ppm} .{ }^{13} \mathrm{C}$ NMR $\left(101 \mathrm{MHz},\left(\mathrm{CD}_{3}\right)_{2} \mathrm{CO}, 25^{\circ} \mathrm{C}\right): \delta=158.2,152.8,140.0$, 137.4, 135.8, 133.0, 130.6, 129.0, 124.6, 63.1, 14.3 ppm. HRMS calculated for $\mathrm{C}_{13} \mathrm{H}_{10} \mathrm{BrN}_{5} \mathrm{O}_{3} \mathrm{Na}^{+}: 385.9859$; found: 385.9868 .

\subsubsection{Ethyl 6-(4-iodophenyl)-4-oxo-4,6-dihy- dro-3H-pyrazolo[4,3-d][1-3]triazine-7-carboxylate (3g)}

This compound was obtained as a yellow solid, 33\% yield; $\mathrm{mp} 178.9$ (dec.). ${ }^{1} \mathrm{H} \mathrm{NMR}\left(400 \mathrm{MHz},\left(\mathrm{CD}_{3}\right)_{2} \mathrm{CO}, 25^{\circ} \mathrm{C}\right)$ : $\delta=13.90(\mathrm{~s}, 1 \mathrm{H}), 7.77-7.54(\mathrm{~m}, 4 \mathrm{H}), 4.38(\mathrm{q}, J=7.1 \mathrm{~Hz}, 2 \mathrm{H})$, $1.27(\mathrm{t}, J=7.1 \mathrm{~Hz}, 3 \mathrm{H}) \mathrm{ppm} .{ }^{13} \mathrm{C} \mathrm{NMR}\left(101 \mathrm{MHz},\left(\mathrm{CD}_{3}\right)_{2} \mathrm{CO}, 25\right.$ $\left.{ }^{\circ} \mathrm{C}\right): \delta=158.2,152.8,140.7,139.1,137.4,135.8,130.6,128.9$, 96.3, 63.1, 14.3 ppm. HRMS calculated for $\mathrm{C}_{13} \mathrm{H}_{10} \mathrm{IN}_{5} \mathrm{O}_{3} \mathrm{Na}^{+}$: 433.9721; found: 433.9710 . 


\subsection{Xanthine oxidase inhibitory activity}

The assay was performed as previously described by Santi et al. [14]. Briefly, the assay medium consisting of $21.4 \mu \mathrm{L}$ of xanthine oxidase solution from bovine milk $(0.04 \mathrm{U} / \mathrm{mL}$, Sigma Chemical Co., St Louis, MO, USA), and $0.75 \mathrm{~mL}$ of the control solution $\left[\mathrm{K}_{2} \mathrm{HPO}_{4} / \mathrm{KH}_{2} \mathrm{PO}_{4}\right.$ buffer $(0.07 \mathrm{M}$, $\left.\mathrm{pH} 7.5)\right]$ or the sample solution (prepared with each compound dissolved in DMSO and subsequently diluted to the appropriate concentrations with the above buffer) were mixed and pre-incubated at $25^{\circ} \mathrm{C}$ for $15 \mathrm{~min}$. Then, $0.45 \mathrm{~mL}$ of the xanthine solution substrate $(150 \mu \mathrm{M}$, Sigma Chemical Co., St Louis, MO, USA) was added and pre-incubated at $25^{\circ} \mathrm{C}$ for $30 \mathrm{~min}$. The reaction was then stopped by the addition of $1 \mathrm{~mL}$ of $\mathrm{HCl}(1 \mathrm{~N})$ and the absorbance was measured at $290 \mathrm{~nm}$ on a Cary Win UV-VIS spectrophotometer, Varian, Inc., Agilent Technologies (Santa Clara, USA). Allopurinol (Sigma Chemical Co., St Louis, MO, USA) was used as positive inhibitor control. Each treatment was replicated three times. The percent inhibition of xanthine oxidase activity was calculated as follows: \% inhibition $=\left[\left(\mathrm{Abs}_{\text {control }}-\mathrm{Abs}_{\text {sample }}\right) / \mathrm{Abs}_{\text {control }}\right] \times 100$, where $\mathrm{Abs}_{\text {control }}$ is the absorbance of the control solution and $\mathrm{Abs}_{\text {sample }}$ is the absorbance of the sample solution.

\subsection{Calculations and statistics}

All assays were independently performed in triplicate, and results were expressed as media \pm SD of three separate experiments. The $\mathrm{IC}_{50}$ values were estimated using the OriginPro 8.0 software on a compatible computer. The results were analyzed by unidirectional analysis of variance (ANOVA) followed by the Bonferroni's test for multiple comparisons using GraphPad Prism 6.0 software.

\subsection{Ligands preparation}

The 3D structures of all PT compounds were built and minimized in $\mathrm{MOE}^{\mathrm{TM}}$ 2105.10. using the MMFF94x forcefield. A conformational search was carried out through the LowModeMD conformational search module [13, 22-24].

\subsection{Protein preparation}

The crystal structure from milk bovine xanthine oxidase in complex with quercetin (PDB ID $=3 \mathrm{NVY}$ ) at 2.0 resolution was obtained from Protein Data Bank (http://www. $\mathrm{rcsb} .0 \mathrm{rg} / \mathrm{pdb}$ ) [25]. All water molecules were deleted, and charges and hydrogens atoms were adjusted with the Amber10 forcefield from MOE ${ }^{\mathrm{TM}} 2105.10$ [13].

\subsection{Docking studies}

Docking studies were performed on MOE software, considering all residues in a sphere of $9 \AA$ centered on the co-crystallized ligand in the $C$ chain. Proxy Triangle was set as placement function. First scoring was calculated with London $\mathrm{dG}$ function, followed by pose refinement and re-scoring with GBVI/WSA dG method. Both algorithms are presented in the Equ. 1SP in the supplementary material. Electrostatic was considered in different aspects. For one hand the used force field (MMFF94x) evaluates the electrostatic interaction by means of Coulomb equation (Eq. 1SP). Partial charges are assessed in the case of ligands (phenols) and an example is shown in the Fig. 1SP of Supp. Mat. On the other hand, the scoring used by the docking process included an evaluation by London dG and GBVI/ WSA dG algorithms above mentioned and an assessment of partial charges given in the same way by the force field. A validation procedure reproducing the same pose of quercetin in the crystal structure with our method with a RMSD value of 0.387 was executed.

\subsection{Structure activity relationship (SAR)}

A qualitative SAR study was performed using the MOE SAR tool that provides a report (web page) housing an interactive view onto the data set of pyrazolotriazinones. The structure-activity report is a MOE application, which generates a web page housing an interactive view onto our collection of molecules. The online report contains a number of tabs for examining the common scaffolds, R-groups, structure vs. activity, fragmentation and, various graphs and interactive widgets. Clark and Labute [16] describes the algorithm used to detect and analyze scaffolds.

\section{2D QSAR model}

A data base of thirteen PT derivatives was used for the QSAR study using MOE software. The $I C_{50}$ values were converted to negative logarithmic $\left(\mathrm{K}=\right.$ plogl $\left.\mathrm{C}_{50}\right)$. Different types of descriptors and their correlation matrix were calculated. A lineal model was built with PLS method with three non-collinear descriptors, all of them associates with XO inhibitory activity.

\section{3D QSAR model}

A rigid body alignment of PT compounds database was used in Open3DQsar software to carry out a Comparative molecular field analysis (CoMFA), relating the molecular interaction of steric and electrostatic fields with bioactivity. 
A $0.5 \AA$ grid for molecular interaction fields calculations was built. The CoMFA steric fields were calculated using the sp3 carbon as the probe atom, following the standard proceed of MMFF94 force field. On the other hand, the CoMFA electrostatic fields were calculated with the quantum mechanics Ab initio method with a Hartree-Fock level of theory with $6-311^{* *}$ functions on Gamess software (version September 30, 2018 R3 for 64 bit) [26]. The steric and electrostatic energy cutoff was set to $30 \mathrm{kcal} / \mathrm{mol}$ and, low variability points (standard deviation $<0.1$ ) were deleted.

A normalization of the relative importance of both fields was performed using the Block Unscaled Weighting (BUW) tool [27].

The validation procedure of 3D-QSAR model was realized with a partial least square (PLS) analysis. Leaveone-out (LOO) method was used to calculate the crossvalidated $\left(\mathrm{q}^{2}\right)$ value and the number of the principal components $(P C)$. Finally, that model was improved using the Smart region definition (SRD) method [28]. This procedure reduces redundancy arising from the existence of multiple nearby descriptors, which basically encode the same kind of information.

\section{Conclusions}

Given the absence of drugs without prejudicial adverse effects to gout disease treatment, the search for therapeutic alternatives is very important.

In this work, we reported the in vitro XO inhibitory activity of thirteen pyrazolotriazinones derivatives. All compounds were active on XO however; none presented an inhibitory activity greater than allopurinol. Considering these results, we proceeded to conduct in silico studies. Those studies allowed us to understand the binding mode PT compounds-XO. Additionally, we present a SAR study and, 2D and 3D QSAR models that describe the observed behavior and provide valuable information for the rational design and synthesis of new PT derivatives with an improved $\mathrm{XO}$ inhibitory activity. Thus, we present here a series of purine analogues as scaffolds for obtaining therapeutic alternative compounds for the of gout disease treatment.

Funding This work was supported by ANPCyT, SECYT-Universidad Nacional de Córdoba, MINCyT. M.G.O., J.P.C and E.L.M are members of the Research Career of CONICET. MDS was postdoctoral student of CONICET, and currently is postdoctoral student of ANII (Uruguay).

\section{Compliance with ethical standards}

Conflict of interest On behalf of all authors, the corresponding authors state that there is no conflict of interest.

\section{References}

1. Okamoto K, Eger BT, Nishino T et al (2003) An extremely potent inhibitor of xanthine oxidoreductase: crystal structure of the enzyme-inhibitor complex and mechanism of inhibition. J Biol Chem 278:1848-1855. https://doi.org/10.1074/jbc.M208307200

2. De Souza MR, De Paula CA, Pereira De Resende ML et al (2012) Pharmacological basis for use of Lychnophora trichocarpha in gouty arthritis: anti-hyperuricemic and anti-inflammatory effects of its extract, fraction and constituents. J Ethnopharmacol 142:845-850. https://doi.org/10.1016/j.jep.2012.06.012

3. Gliozzi M, Malara N, Muscoli S, Mollace V (2016) The treatment of hyperuricemia. Int J Cardiol 213:23-27. https://doi. org/10.1016/j.ijcard.2015.08.087

4. Nepali K, Singh G, Turan A et al (2011) A rational approach for the design and synthesis of 1-acetyl-3,5-diaryl-4,5-dihydro $(1 \mathrm{H})$ pyrazoles as a new class of potential non-purine xanthine oxidase inhibitors. Bioorg Med Chem 19:1950-1958. https://doi. org/10.1016/j.bmc.2011.01.058

5. Dong $Y$, Huang $H$, Zhao $M$ et al (2016) Mechanisms underlying the xanthine oxidase inhibitory effects of dietary flavonoids galangin and pinobanksin. J Funct Foods 24:26-36. https://doi. org/10.1016/j.jff.2016.03.021

6. Ishibuchi S, Morimoto H, Oe T et al (2001) Synthesis and structure-activity relationships of 1-phenylpyrazoles as xanthine oxidase inhibitors. Bioorg Med Chem Lett 11:879-882. https:// doi.org/10.1016/S0960-894X(01)00093-2

7. Pacher P, Nivorozhkin A, Szabo C (2006) Therapeutic effects of xanthine oxidase inhibitors. Hum Physiol 58:87-114. https://doi. org/10.1124/pr.58.1.6.87

8. Nishino T, Okamoto K (2015) Mechanistic insights into xanthine oxidoreductase from development studies of candidate drugs to treat hyperuricemia and gout. J Biol Inorg Chem 20:195-207. https://doi.org/10.1007/s00775-014-1210-x

9. Rodrigues MVN, Barbosa AF, Da Silva JF et al (2016) 9-Benzoyl 9-deazaguanines as potent xanthine oxidase inhibitors. Bioorg Med Chem 24:226-231. https://doi.org/10.1016/j. bmc.2015.12.006

10. Zhang J, Dierckx R, Mohee K et al (2017) Xanthine oxidase inhibition for the treatment of cardiovascular disease: an updated systematic review and meta-analysis. ESC Hear Fail 4:40-45. https://doi.org/10.1002/ehf2.12112

11. Moyano EL, Colomer JP, Yranzo GI (2008) New application of heterocyclic diazonium salts: synthesis of new pyrazolo[3,4-d] [1,2,3]triazin-4-ones. Eur J Org Chem. https://doi.org/10.1002/ ejoc.200701109

12. Colomer JP, Moyano EL (2011) New application of heterocyclic diazonium salts. Synthesis of pyrazolo[3,4-d][1,2,3]triazin4-ones and imidazo[4,5-d][1,2,3]triazin-4-ones. Tetrahedron Lett 52:1561-1565. https://doi.org/10.1016/j.tetlet.2011.01.040

13. Molecular Operating Environment (MOE) 2015.10

14. Santi MD, Paulino Zunini M, Vera B et al (2018) Xanthine oxidase inhibitory activity of natural and hemisynthetic flavonoids from Gardenia oudiepe (Rubiaceae) in vitro and molecular docking studies. Eur J Med Chem. https://doi.org/10.1016/j.ejmec h.2017.11.071 
15. Lin S, Zhang G, Liao Y, Gong D (2016) The inhibitory kinetics and mechanism of dietary vitamins D3 and B2 on xanthine oxidase. Food Funct 7:2849-2861. https://doi.org/10.1039/c6fo00491a

16. Clark AM, Labute $P$ (2009) Detection and assignment of common scaffolds in project databases of lead molecules. J Med Chem 52:469-483

17. Tosco P, Balle T (2011) Open3DQSAR: a new open-source software aimed at high-throughput chemometric analysis of molecular interaction fields. J Mol Model 17:201-208. https:// doi.org/10.1007/s00894-010-0684-x

18. Cramer RD, Patterson DE, Bunce JD (1988) Comparative molecular field analysis (CoMFA). Effect of shape on binding of steroids to carrier proteins. J Am Chem Soc 110:5959-5967. https://doi. org/10.1021/ja00226a005

19. Zhi H, Zheng J, Chang Y et al (2015) QSAR studies on triazole derivatives as sglt inhibitors via CoMFA and CoMSIA. J Mol Struct 1098:199-205. https://doi.org/10.1016/j.molstruc.2015.06.004

20. Abdizadeh R, Hadizadeh F, Abdizadeh T (2019) QSAR analysis of coumarin-based benzamides as histone deacetylase inhibitors using CoMFA, CoMSIA and HQSAR methods. J Mol Struct. https ://doi.org/10.1016/j.molstruc.2019.126961

21. Fasihi Mohd Aluwi MF, Rullah K, Koeberle A et al (2019) Design and synthesis of a novel mPGES-1 lead inhibitor guided by 3D-QSAR CoMFA. J Mol Struct 1196:844-850. https://doi. org/10.1016/j.molstruc.2019.07.004
22. Allen MP, Tildesley DJ (1987) Computer simulation of liquids. Oxford University Press, Oxford, pp 231-232

23. Halgren TA (1999) V.I. MMFF, MMFF94s option for energy minimization studies. J Comput Chem 20:720-729

24. Labute $P$ (2010) LowModeMD-implicit low-mode velocity filtering applied to conformational search of macrocycles and protein loops. J Chem Inf Model Inf 50:792-800

25. Berman HM, Westbrook J, Feng Z et al (2000) The protein data bank. Nucl Acids Res 28:235-242

26. Schmidt MW, Baldridge KK, Boatz JA et al (1993) General atomic and molecular electronic structure system. J Comput Chem 14:1347-1363

27. Kastenholz MA, Pastor M, Cruciani G et al (2000) GRID/CPCA: a new computational tool to design selective ligands. J Med Chem 43:3033-3044. https://doi.org/10.1021/jm000934y

28. Pastor M, Cruciani G, Clementi S (1997) Smart region definition: a new way to improve the predictive ability and interpretability of three-dimensional quantitative structure-activity relationships. J Med Chem 40:1455-1464. https://doi.org/10.1021/jm9608016

Publisher's Note Springer Nature remains neutral with regard to jurisdictional claims in published maps and institutional affiliations. 